Christopher Todd Beer

The Global South. Vol. 8, No. 2, The Global South and/in the Global North: Interdisciplinary Investigations (Fall 2014), pp. 84-100

\title{
Climate Justice, the Global South and Policy Preferences of Kenyan Environmental NGOs
}

\begin{abstract}
Negotiations for a global agreement to address climate change have often pitted the nations of the heavily industrialized Global North against the nations of the developing Global South. The Global North has tended to emphasize the common responsibilities of all nations to reduce emissions while nations of the Global South have tended to place more emphasis on the differentiated responsibilities. The Global North-South negotiating positions are derived from the inequality in: the historical and current emissions of greenhouse gasses, the emerging consequences of climate change, and the geo-political negotiating power between nation-states. However, these broad sweeping categories miss diverse goals and policy preferences among civil society actors within nations. Through in-depth, in-person interviews, this research documents the surprisingly strong presence of Global North policy preferences among the field of Kenyan environmental NGOs - a field that is significantly divided among the "climate justice" policy priorities strongly associated with nations of the Global South and "emissions reductions for all" priorities associated with nations the Global North. Qualitative data captures the rationale of KENGOs for the respective policy script preferences. Utilizing the nation-state as a unit of analysis would miss this variation among civil society actors within the Global South, variation that demonstrates the complex interaction between the diffusion of global policies and domestic social contexts.
\end{abstract}

Does the terminology of "Global South/North" mask important differences among civil society actors within nations? While the Global South/North broadly describes shared contexts levels and pathways of development, geopolitical power, historical colonial and post-colonial relations - the terms often fail to "serve as a signifier of oppositional subaltern cultures" (Lopez 8). This paper investigates the complexities of actors within the Global South through a case study of Kenyan environmental organizations' global climate change policy preferences.

\section{Global South - North Divide}


Negotiations to collectively address climate change have been riddled with conflict between the nations of the Global South and North since the inception of the United Nations Framework Convention on Climate Change (UNFCCC) in 1992 (Linner and Jacob; Roberts and Parks; Muller). This conflict is derived from the inequality of the two regions' historic and current greenhouse gas (GHG) emissions. While having contributed a fraction of the historical GHG emissions, the Global South is currently experiencing the greatest harm (IPCC). Compounding the problem, the Global South is not financially to adapt to the changing climate. The founding UNFCCC treaty addresses the inequality between the North and South, stating that nations should act “...in accordance with their common but differentiated responsibilities and respective capabilities" (UNFCCC 1). In the global negotiations, heavily industrialized nations of the Global North have emphasized the common responsibilities of nations while developing nations have tended to place more emphasis on the differentiated responsibilities (Baumert, Bhandari and Kete). At the global level, the sweeping labels of "North" and "South" distinguish two very different experiences and positions regarding global climate change.

Historical and current divisions have resulted in the South's skepticism of the North's motives and generated fears of arrested development from globally imposed environmental regulations (Najam). Because climate negotiations "take place in the context of an ongoing development crisis and what the global South perceives as a pattern of Northern callousness and opportunism in matters of international political economy" we can expect "it [to be] more difficult for rich and poor nations to identify socially shared understandings of 'fair' solutions" (Roberts and Parks 23, 27).

Because of the fundamentally different national views between the North and South, the nations of the Global South often negotiate as a block known as the G77 (Kasa, Gullberg and 
Heggelund). The G77, founded in 1964, currently represents 133 developing nations and contains sub-groups within the organization including the African states, Alliance of SmallIsland States (AOSIS), and the Least Developed Countries. At the 2009 global climate negotiations, the unity of the G77 weakened. Fast-developing Brazil, South Africa, India, and China (BASIC) failed to support others in the G77 in negotiating a new legally binding treaty with ambitious emission reduction commitments from the BASIC nations (Vihma). Through their resistance, the BASIC nations prioritized their path of rapid development and maintained the dichotomous distinction between developed and developing countries. The greatest pressure from within the G77 came from AOSIS, whose nations are literally disappearing under rising sea levels. AOSIS called for drastic emissions reductions from every nation without regard to differentiated responsibilities. At the same time the Africa Group within the G77 focused more on adaptation, technology transfer, and finance (Masters). In some respects a division among nations of the Global South emerged between those fearful of arrested development from emissions reductions and those fearful of the immediate detrimental consequences of climate change emissions produced by all.

While these divisions may have emerged, the G77 plus China continue to work in a unified manner, as evident in the collective statement they released just weeks after the 2009 negotiations stating their dissatisfaction with both the negotiating process and the substantive outcome (Mohamad). The nations of the Global South remain held together by a common view of the "inadequacy of Northern action on climate change, ... [a] collective sense of an 'unjust world order', ... [and a] trust deficit towards developing countries" (Vihma 8-9). Even after the 2009 COP meeting, nations of the Global South see that "the value of the G77 and China is in 'solidarity', or the ability to present a collective voice from the South" (Masters 3). 
Collectively, the nations of the Global South have argued that any climate agreement should include historically-based emissions reductions, financial compensation to developing nations, and directly connecting climate change and sustainable development (Najam, Huq and Sokona; Linner and Jacob; Sokona and Denton). The nations of the Global South argue that the North should bear the brunt of the commitments to reduce emissions and incur the costs of addressing the damages of climate change (Anand). The nations of the South argue that they "should be awarded compensation and at the very least assistance to overcome the additional challenges that adopting policies for mitigating and/or adapting to global warming would present to them" (Pettit 103). Additionally, the nations of the South are resistant to emissions reduction commitments occurring through clean development mechanisms (CDM) or a market based carbon-trading system, arguing that these options allow the North to simply "buy its way out of altering its unsustainable consumption patterns by trading carbon credits with the South" (Pettit 103).

\section{The African Position}

African nations, including Kenya, share both little responsibility for the historical accumulation of GHGs in the atmosphere and similarly high risks of detrimental consequences with few financial resources to adapt. While also a part of the G77, in 2009 the African Union (AU) put forth the Nairobi Declaration on the African Process for Combating Climate Change as the common negotiating position for African nations (UNEP). As part of the AU, Kenya was aligned with this policy declaration. The key provisions call for the nations of the North to reduce their emissions dramatically by 2050 and to compensate African nations for 
environmental and economic losses. Lastly, the AU demanded that any efforts by African nations to mitigate climate emissions be voluntary.

African heads of state called for a common African position that "gives Africa an opportunity to demand compensation for damages caused by global warming" (African Union 1). In 2009, a concept note prepared for the first meeting of the Conference of African Heads of State and Government on Climate Change (CAHOSCC) called for developing nations to receive at least $\$ 67$ billion a year by 2020 to support adaptation and $\$ 200$ billion $(0.5 \%$ of the GDP of OECD countries) to support mitigation efforts. The final AU position called for financial support to developing nations equivalent to $1.5 \%$ of the GDP of developed nations. Broadly, the policy preferences of the AU and the nations of the Global South have congealed into what is commonly known as "climate justice".

\section{Climate Justice}

The ideals of climate justice have emerged from the thousands of social movements advocating for global justice and environmental justice (Goodman). Globally, climate justice began to gain ground beginning in 2000 when the first Climate Justice Summit was held at the Hague parallel to the UNFCCC's Conference of Parties (COP) meeting (Karliner). The summit was sponsored by corporate watchdog and environmental groups from the US, Europe, Africa, and South America. In 2002, a coalition of organizations released the Bali Principles of Climate Justice. The document calls for the "victims of climate change and associated injustices to receive full compensation, restoration and reparation for the loss of land, livelihood, and other damages" (International Climate Justice Network). 
In 2007, at the UNFCCC meeting in Bali, actors from climate justice movements were visible participants, influencing the issues and emboldening developing nations (Ott, Sterk and Watanabe). It was here that a coalition of social movement organizations known as Climate Justice Now! was formed. Among the solutions they proposed included "huge financial transfers from North to South based on historical responsibility and ecological debt for adaptation and mitigation" (Climate Justice Now!). By the much anticipated 2009 COP 15 in Copenhagen, the climate justice movement was a prominent voice (Tokar). During the parallel summit to COP 16 in Cancun in 2010, a coalition of organizations demanded that the North be held "accountable for their gross and systematic crimes against humanity and nature and begin urgent reparations of their historical, ecological, climate, and social debts" (South-South Summit on Climate Justice and Finance). In April of 2010, the World People's Conference on Climate Change and the Rights of Mother Earth was organized by Bolivian President Morales and called for developed countries to recognize their "climate debt" and assume financial responsibility for climate adaptation in developing nations (PWCCC).

Climate justice arguments are rooted in the social context and historical events that nations of the South share in common (Roberts and Parks). Climate justice has become normatively powerful - the expected values of not only states, but also organizations and individuals of the South. Due to commonalities in the emissions contributions and detrimental consequences of climate change, climate justice has emerged as the likely, if not predominant, policy preference of actors in the South. Subsequently, we would expect that the vast majority of civil society actors in individual nations, such as the case study presented below, also endorse the climate justice policies. Just as the term "Global South" congealed around nations with shared geo-political positions and globally intertwined development experiences, climate justice has 
emerged as an alternative view to that of the North. From a global view of nation-states, the existing literature argues that climate justice is the predominant position of the South, however the research presented here explores the reality on the ground among civil society actors that are commonly treated as a homogenous group.

\section{Data and Measures}

Kenya was chosen as a case study for the Global South, due to its relative political stability, the prevalence of English, and its slightly above average Human Development Index, but most importantly due to the strength of its civil society. Additionally, Kenya is well embedded in global environmental politics: the UN Environmental Program is headquartered in

Nairobi, and the $12^{\text {th }}$ COP climate change negotiations and the $7^{\text {th }}$ World Social Forum were held in Nairobi.

To determine the population of Kenyan environmental nongovernmental organizations (KENGOs) I utilized the electronic database of the Kenyan NGO Coordination Board. A keyword search of organization's self-reported objective distinguished environmental NGOs. From the initial national population of 369 organizations, all 233 organizations located in the top population centers of Kenya were selected. These include the capital and most populated city, Nairobi, and the next four most populated cities: Mombasa, Kisumu, Nakuru, and Eldoret. This geographically disperse selection ensured a diversity of organizations and did not limit the effects measured to only those in Nairobi, which likely have an advantage over those outside of Nairobi due to the population, material and communication resources, and exposure to transnational actors. The sample also accounted for logistical challenges of conducting in-person interviews in more rural and remote communities that often lack access to reliable public 
transportation, secure accommodation, and modern communication. Of the 233 KENGOs in the top population centers, 103 had active contact information and interviews were completed with 75 of these. For this particular analysis, four cases were dropped due to missing data, resulting in a final sample of 71 KENGOs.

To assess the global climate change policy priorities, in-person interviews were conducted with directors of KENGOs during the first half of 2010. The interviews occurred at a location of the director's choosing, most often their office or a nearby coffee shop. With the director's permission, the interviews were audio recorded and later transcribed. On average, the interviews lasted 60 minutes with a range of 30 to 100 minutes. Interviews occurred in English, one of two predominant languages spoken in Kenya.

In order to measure support for particular global climate change policies, executive directors or environmental program directors were asked to rank (with pen and paper), in order of importance, five statements reflecting the policy debate within the global climate change negotiations. The items were as follows:

1. All countries must reduce their greenhouse gas emissions drastically by 2020 .

2. Emissions reductions should be based on the historical amount of emissions produced by each nation.

3. Developed, industrialized nations should compensate developing countries for the damage caused by global climate change.

4. Emissions reductions should be accomplished through an economic market-based mechanism like carbon trading.

5. New, cleaner, alternative sources of energy must be developed.

These five items were designed to broadly capture the essential debates that have divided nations of the Global North and South in climate negotiations. The nations of the North, negotiating for all nations (developed and developing) to commit to emissions reductions through market based carbon trading and the promotion of new, cleaner sources of energy. The 
Global South nations have focused their policy negotiations more on the historical responsibility for greenhouse gas (GHG) emissions, the subsequent need for drastic emissions reductions to come from nations of the North, and financial transfers from the nations of the North to the South to compensate for the harm caused by climate change. In particular the third item in the scale, calling for financial compensation, reflects the ideals of equity-based climate justice and is expected to emerge as a top priority among KENGOs as it has among other actors of the Global South. Subsequently, the other policy statements, especially those calling for emissions reductions for all or market-based carbon trading would be ranked lower.

Unlike a dichotomous measure, forcing the prioritization of these policy statements measures the strength of subjects' feelings and reflects the reality of any sort of negotiations where actors have to decide which elements are most important to them and which they are willing to subject to compromise. In order to analyze the most important preferences among KENGOs, I focused on the top two ranked items on the five-item scale - considering items ranked as one and two as the actors' top priorities. I then coded the actors' responses into a typology based on similar sequencing of policy priorities. Most often these aligned with competing global policies of the North and South.

\section{Policy Priorities}

As reported in table 1 below, the climate justice policy was prioritized by only $42 \%$ of the KENGOs' directors while the North's "emissions reduction for all" policy was prioritized by $38 \%$. The third policy preference group to emerge was "carbon market/clean energy". For these KENGO directors the policy preferences of market based mechanisms, such as carbon trading, to reduce emissions combined with developing new, cleaner sources of alternative energy were 
ranked in some combination of their top two priorities. Nine KENGO directors or $13 \%$ of the total sample prioritized this policy.

Table 1

Frequency Distribution of Global Climate Change Policy Priority by Kenyan Environmental NGO Directors

\begin{tabular}{lrr}
\hline Policy Priority & $\mathrm{n}$ & \multicolumn{1}{c}{$\%$} \\
\hline Climate Justice & 30 & 42 \\
Emissions reductions for all & 27 & 38 \\
Carbon Market / Clean energy & 9 & 13 \\
Other & 5 & 7 \\
\hline Total & 71 & 100
\end{tabular}

Counter to the expectation based on the macro Global North-South perspective that actors within Kenya would adopt the climate justice policy, we see that the "emissions reduction for all" policy receives near equal rates of support (38\% to $42 \%)$ as the climate justice policy.

\section{The Logic of Policy Priorities}

The initial evidence indicates that the adoption of global policy priorities by KENGO directors is diverse and far from unified. Exploring the rationale behind their responses will provide a more thorough and nuanced understanding of their adoption of particular policy priorities. Why do actors rooted in the South choose to adopt or reject a particular global climate change policy? Results of an open-ended, follow-up question are explored below.

\section{Support for "Climate Justice”}

Two-thirds of the $30 \mathrm{KENGO}$ directors that supported climate justice expressed a punitive, polluter-pays view of climate change. Many recognized that while Kenya has contributed very little to the causes of global climate change, they were already feeling negative 
consequences and subsequently compensation was fair and just. The following quotes are representative of this sentiment:

Compensation is important because [industrialized nations] are the main influence damaging the globe. So, if you damage you pay. (KENGO interview 0330a)

The bigger polluters of the environment are industrialized countries. In Kenya when we look at our emissions it's not there. We are just victims. The culprits are the industrialized nations emitting a lot of carbon. So why should we suffer? We need to be compensated. (Interview 0511a)

In addition to a focus on compensation, $17 \%$ of the KENGO directors supporting climate justice recognized the historical nature of GHG accumulation and the long-term inequality in levels of industrialization, development, and trade.

Because the issue of climate change is as old as industrialization and industrialization began in Europe, the developed world, so I think it is developed countries that are really causing this climate change issue because the big technologies come from there. The raw materials are sourced on other continents - Africa, Latin America, basically the third world. So I think the developed countries must really compensate. (Interview 0521a) 
The quote above reflects an understanding of the industrially-advantaged position of many nations of the Global North which are able to extract less-valued raw materials from the Global South and turn them into higher valued products through emissions-producing industrialization. While recognizing that the North had contributed the majority of the emissions, nearly a quarter of the KENGO directors that supported climate justice expressed the desire for compensation not so much out of a sense of punitive justice, but rather to directly help reduce emissions, deforestation, and existing environmental issues in Kenya and the Global South.

You cannot compare Kenyan emission with the US. [Industrialized nations] should be held accountable, the best I think they can do is ...they can give African countries money and monitor the propagation of trees. (Interview 0414)

The first thing is to get the major polluters, get those guys just to pay up and let the Third World countries benefit, and not just benefiting by giving them money. Let them use that money to address environmental destruction. The Third World countries and to be specific, Africa...we are the least emitters of the greenhouse gases and yet it's we who are paying heavily.... So if those guys can own up, can pay and let the third world benefit. Not just benefit by eating the money, but to address environmental issues. (Interview 0416b)

In explaining why they adopted the climate justice policy, just a few KENGO directors recognized that the particular path of industrial development taken by nations of the North utilizing powerful carbon-based energy - would not be available to them. In these directors' 
minds, compensation was necessary to help them develop using low-carbon energy sources. For example, as one director said:

We are saying that development is going to be very difficult for developing countries under the new green economies system. If we want a world of madmen then we can allow [fossil fuel-based development] to happen, but if we don't want that, then we should be able to support development under difficult conditions. We would have liked to develop just like anybody else, following the [path] of development that probably emits a lot of greenhouse gases into the atmosphere. But again, is it going to be good for anyone? No. We are saying that is the best way out, if we really were to look at the world as our place, our planet where we need to live, all of us. Give others an equal chance to develop. (Interview 0708a)

Finally, a couple of the KENGO directors argued that compensation would motivate Northern countries to begin addressing the issue by reducing their emissions.

The industrialized countries are the ones producing these emissions....They are the ones producing more and more and at the end of the day it affects the developing countries. [Compensation] will force them to adhere to the agreement because they will have the pain of compensating and in the long run they will see how they can reduce the emissions. (Interview 0212) 
Among the KENGO directors aligned with the South's climate justice policies, a punitive sense of justice was the most prevalent explanation for supporting climate justice. However, others saw compensation, less as an issue of justice and more an issue of funding to help Kenyans address ongoing environmental degradation. Some even expressed concerned about Kenya's small contribution to global emissions through deforestation and saw compensation as a way to facilitate the replanting of degraded Kenyan forests. Others recognized the challenge faced by developing countries to develop further in the light of the global need to curb carbon emissions. Based on much of the existing literature, this is what we would expect from actors within the South. However, most KENGO directors did not support the key tenants of climate justice. Below, I examine the logic of directors that failed to adopt the South's climate justice policy.

\section{Failure to Prioritize "Climate Justice”}

The explanations of those KENGO directors that did not support climate justice can be categorized into three logics: 1) Compensation does not reduce emissions, 2) Compensation will be misused, and 3) We are all contributing to climate change or benefitting from the industrialization that generates emissions. Below I further elaborate each of these explanations with qualitative data from the interviews.

Twenty-five KENGO directors that failed to support climate justice argued that financial compensation by developed nations of the Global North would not reduce GHG emissions. Many expressed that the best solution to climate change is for everyone to reduce emissions and that compensation, rather than an important element addressing justice and fairness, was a 
harmful diversion from those efforts. The following quote is reflective of these types of explanations:

[Compensation] is not important at all because compensation does not really reduce carbon emissions. I think one must look at the source of the carbon emissions and deal with it. That would be more adequate than compensation for everybody because at the end of the day what we must not have is global warming. Compensation will not change the climate. (Interview 0413)

Additionally, several directors expressed the urgency of reducing emissions as the reason that compensation was a lower priority than drastic emissions reduction by all nations. They not only prioritized emissions reductions by all nations, but emphasized the importance of doing so immediately to avoid exacerbating the climate crisis.

We shouldn't continue waiting for compensation. We need to do something. It's urgent.

(Interview 0430)

In my view, this [compensation] does not solve climate change. I don't know how they wanted to compensate. But now in my view this may not give us the result soonest. Fine you can get money, maybe ten billion, but it will not give you the results soonest. (Interview 0511c) 
Among KENGO directors that were concerned that compensation would not contribute to the reduction of emissions, four expressed that compensation would serve as justification by the North to actually continue to emit. Not all of them dismissed the idea of compensation in totality, but emphasized that emissions reductions must come first.

Why I thought that [compensation] was less important was that even if [nations of the North] compensate us then they will feel that they have paid for the polluting and they will just continue to emit. They will not reduce their emissions, so for me it is reducing, period. (Interview 0202.2)

The issue of compensation can come in later but it is like putting the cart before the horse. Because even if you are compensated and the same thing is being done what's the need? You guys from the first world have to stop the emissions. (Interview 0322)

The other predominant explanation used by nine of the KENGO directors that failed to adopt the climate justice policy was a strong belief that the funds would be misused. This was based on a lack of trust in the Kenyan government and its politicians. Some directors expressed great concern over government corruption and the influence of money.

What would we do? For example, give Kenya 100 billion in compensation. What will happen with that money? Some people will start looking to take it home, do nothing with it, and even if they are to do something with it, what something? Do 
we have the capacity to do the research, invent new machines that can control the emissions in the atmosphere? I don't know but I don't think we do. I can compensate you but if I compensate you what do you do with that money? Do I compensate you to go and put it in your pocket? (Interview 0128)

So our leaders are saying that we need to be compensated. This is a political gimmick to get some money from the developed countries. We should sit down and say fine this is a problem how should we face it? (Interview 0315b)

As is evident in the initial quote above, the belief that funds would be misused was also explained by a lack of belief in the capacity of Kenya and other African nations to take the most effective actions with any compensatory funds. This sentiment was repeated by a number of directors. Whether it is the capacity to generate technological solutions or the capacity to simply manage the amount of money that is being demanded, as expressed below, there were serious reservations about their collective abilities.

So I say let's forget out about this whole idea of compensation. What is the issue at hand? We need to build resilience. You know some of the figures that are being floated? We don't even have the capacity. What if you gave us 200 billion every year? We are struggling to manage the little budget that we have and there is a lot of waste. (Interview 0219)

Lastly, KENGO directors expressed concern that any funds would not help those who really needed it - the poor and vulnerable. They expressed a belief that the money being 
demanded in the negotiations by the formal institutions, the state, and the African Union, would not benefit the poor in their constituencies. The examples below are illustrative quotes from these kinds of explanations. Additionally, in the first quote below the subject expresses concerns about national capacity and the need to just reduce emissions as we have seen in previous responses.

My main concern is really what happens to the person in the village. At the moment, I do not think that many countries in Africa have the capacity to even absorb that compensation if it were to be given. To me the priority is that, one we have a clean environment within which even if we are poor we are able to survive. Survival to me is key rather than being compensated because really compensation is as good as what we are going to do with that compensation and I think for many African countries they do not have the systems to absorb that compensation. (Interview 0623)

Then the other reason is even if the developing nations are compensated...to me I don't see any meaningful change that the developing countries will do. They will be given what it is that they have been asking for and the poor communities will continue suffering. (Interview 0329)

Inherent in these explanations is a deep mistrust of Kenyan politicians. The KENGO directors were doubtful that any funds would help the poor, but rather would "disappear" through political corruption into the pockets of those in seats of power. Directors also express a mistrust of the material power of the North believing that if compensation was given, it would be used to 
justify the continuation of harmful emissions. Additionally, several did not believe the state had the capacity to manage the funds in productive ways that would effectively address climate change.

Among the nearly dozen KENGO directors that expressed mistrust in the state to handle compensatory funding in the name of climate justice, most were consistent with their expression of mistrust and not just utilizing it to explain their lack of support for climate justice policies. Over two-thirds of them expressed a general mistrust of the current state administration in a previous question early in the interview schedule. Only two directors expressed a high level of general trust in the current government while later expressing concern over the misuse of potential climate justice funds. The Kenyan state is in transition towards greater democracy and the level of trust of the state is bound to vary as the process continues.

A final explanation given by six of the KENGO directors that did not adopt the climate justice policy preference was that they believe that everyone, including Kenyans, is contributing and/or benefitting from the activities that cause climate change in some way. While recognizing that there were in fact significant differences in the contribution to the problem of climate change, several argued that Kenya needs to acknowledge its role and not look to blame others through the demands of compensation.

No, no I don't think compensation would be correct because all of us have been responsible for the climate change in one way or the other. Of course some bear the bigger part of the blunder, especially the developed countries. But it doesn't mean the developing countries have not contributed a lot to this condition. So asking the developed countries to compensate the developing countries for the damage of climate change is not a fair thing to say. It is not a crime that has been 
committed against developing countries as such. If you ask me I would say that all of us have been responsible in one way or the other. It is a global concern although the developed countries bear a bigger part of the blame. (Interview 0408)

Compensation is a poor argument. This is a global problem and we are in it together. If we have a sense of membership and approach the climate problem with a lot of intelligence, with creativity... we have a very small window if the science is correct. (Interview 0219)

Interestingly, a few KENGO directors acknowledge that while much more industrialization and GHG emitting occurs in developed nations of the North, everyone in the world consumes and benefits from these products. In a similar vein, when international factories locate in Kenya, they argued that Kenyans benefit. In these opinions, Kenya is as much of an accomplice to the causes of global warming due to the local consumption of products that are manufactured by industries of the North. Therefore, developed nations should not be singled out through demands for compensation for what, in their view, has benefitted Kenya and many others.

We are all destroying the world. We are destroying the planet. And I know Africa...some of us took this matter to Copenhagen. Compensated how? Why? Which way? If an American or German company brings a factory to Kenya that factory will not only help him. I will also benefit. Am I not going to work there? Am I not going to then pay taxes to the government? If the factory is producing 
food, will I not taste some food from it? Take Coca-Cola. You know I drink Coca-Cola. You make planes. Do I not board that plane? You may need that plane a lot, but I also need it. I go myself and go and buy that plane and bring it to Kenya. You don't force me to buy your planes do you? We ourselves from the socalled Third World also produce something that is harmful to the environment. I believe that everybody should participate. (Interview 0128)

This final group of explanations argued that we are all responsible in some way, whether someone lives in a developed or developing nation, the Global North or the Global South. These directors choose not to prioritize compensation, a key element of climate justice, because they view Kenya's contribution through deforestation as equal to that of the North's GHG emissions. Additionally, they argue that industrialization and manufacturing, whether it is done in nations of the North or by Northern companies in the South, benefits the citizens of Kenya. This represents a dramatically different worldview than one embedded in a North-South, developed-developing nation view.

\section{Discussion}

Exploring the support for climate justice among civil society actors within a national context shows greater diversity than the often-implied homogeneity of the terms "Global South/North". Civil society actors in Kenya are situated in the same social-historical context that generated the categorization of the Global North/South; KENGOs' constituents are exposed to poverty, increasingly unpredictable rains, and damaged livelihoods from climate change predominantly caused by industrialization in the North. Civil society actors in the South, 
occupying the same conditions that have driven the emergence of climate justice arguments, should theoretically support the policies of climate justice. By looking more closely - on the ground - I find that less than half do.

The global climate change policy preference of states of the Global North is present in the South, in Kenyan civil society, in the form of support for emissions reductions by all nations. This Global-North-like position ignores the historical exploitation, industrial development, and emissions by the North in favor of a sole focus on emissions reductions. After years of slow moving global negotiations and increasingly dire warnings from scientists, many of the KENGO directors seem to be willing to forgo the political debates of compensation in favor of pragmatically addressing the source of the problem - GHG emissions.

For others, compensation felt like the nations of the North were actually shirking their responsibility to reduce emissions. Wanting to prevent Northern nations from "buying" their way out of responsibility, some KENGO directors wanted to focus on that which seemed harder for nations of the North to actually commit to - again, reducing GHG emissions. In a world of great financial inequality between nations, these Kenyan actors failed to trust the states of the North to fulfill commitments of emissions reductions if financial compensation was also provided.

Some Kenyan civil society actors rejected the Global South's climate justice argument because they believe one of its primary components - financial transfers -will be misused or misappropriated. This feeling stems from mistrust of their own state and a sense of corruption among its officials. Lacking trust in the Kenyan state, KENGO directors were not willing to support the further empowerment of politicians with added financial resources. Additionally, Kenyan civil society actors had questions about their own society's capacity to address the issue though technological advances and knowledge. Working to change society through the efforts of 
civil society is often a slow process and some of the KENGO directors had a pessimistic outlook of their own society's capacity to innovate change and subsequently doubted its capacity to address climate change.

Lastly, Kenya environmental organizations failed to support the principles of climate justice because they failed to see the North-South division in production and consumption in favor of a more level worldview, where everyone benefits from industrialization and globalization and therefore contributes to the climate problem equally. The professional credentials and position of many (but certainly not all) KENGO directors places them in a financial position to benefit from some of the exchange of economic globalization, resulting in a more positive outlook on the process.

This article points to a critical role of trust in the state influencing one's support for particular global policy initiatives. Among civil society actors in the Global South mistrust in the nation-states of the North may generate greater support for policies that ensure verifiable action by Northern states; mistrust in the their own nation-state in the Global South may weaken support for global policies that seek compensatory justice channeled through the state.

Is the terminology of the Global South/North prima facie too geographically rooted? Is it rooted in national boundaries situated on the rungs of a global development/power hierarchy or is it a set of values and a worldview not tied to nation-state boundaries? Based on the research elaborated above, being located - physically, economically, and historically - in the Global South does not ensure support for the principles of climate justice. Further research and thought should be given as to whether new terminology, lacking geographical reference, better captures the solidarity of those who are disadvantaged, disempowered, and dispossessed by the global structure, whether they live in the Global South or North. 


\section{Works Cited}

African Union. "Concept Note for the First Meeting of the Conference of African Heads of State and Government on Climate Change and African Lead Experts on Climate Change." July 2, 2010 2009. Web. March 3 2010. <http://www.africaunion.org/root/ua/Conferences/2009/aout/SUMMIT/24aout/Concept Note CONFERENCE OF AFRICAN HEADS OF STATE AND GOVERNMENT ON CLIMATE CHANGE.DOC\%3E.

Anand, Ruchi. International Environmental Justice: A North-South Dimension. Burlington, VT: Ashgate, 2004. Print.

Baumert, Kevin A., Ruchi Bhandari, and Nancy Kete. "What Might a Developing Country Climate Commitment Look Like." World Resources Institute, Washington DC 15 (1999). Print.

Climate Justice Now! "What's Missing from the Climate Talks? Justice!" 2007. Web. March 7, 2010. $<$ http://www.climate-justice-now.org/category/events/bali/\%3E.

Goodman, James. "From Global Justice to Climate Justice? Justice Ecologism in an Era of Global Warming." New Political Science 31.4 (2009): 499-514. Print.

International Climate Justice Network. "Bali Principles of Climate Justice." 2002. Web. October 12, 2009. <http://www.wrm.org.uy/actors/WSSD/Bali.html\%3E.

IPCC. Climate Change 2007: Synthesis Report. Retrieved October 12, 2009 (http://www.ipcc.ch/publications_and_data/ar4/syr/en/contents.html)2007. Print. Karliner, Joshua. "Climate Justice Summit Provides Alternative Vision." 2000. Web. April 7, 2010. $<$ http://www.corpwatch.org/article.php?id=977\%3E. 
Kasa, Sjur, Anne T. Gullberg, and Gorild Heggelund. "The Group of 77 in the International Climate Negotiations: Recent Developments and Future Directions." International Environmental Agreements: Politics, Law and Economics 8.2 (2008): 113-27. Print.

Linner, Bjorn-Ola, and Merle Jacob. "From Stockholm to Kyoto and Beyond: A Review of the Globalization of Global Warming Policy and North-South Relations." Globalizations 2.3 (2005): 403-15. Print.

Lopez, Alfred J. "Introduction: The (Post)Global South." The Global South 1.1 \& 2 (2007). Print. Masters, Lesley. Policy Brief the G77and China in the Climate Change Negotiations: A Leaky Umbrella?: Institute for Global Dialogue, 2014. Print.

Mohamad, Abdalmahmood Abdalhaleem. "Statement by the Chairman of the Group of 77, at the Informal Meeting of the Plenary of the General Assembly to Hear a Briefing by the Un Secretary-General on the Outcome of the Un Climate Change Conference (New York, 21 December 2009)." 2009. Web. December 22014. $<$ http://www.g77.org/statement/getstatement.php?id=091221\%3E.

Muller, Benito. Equity in Climate Change: The Great Divide. Oxford: Oxford Institute for Energy Studies, 2002. Print.

Najam, Adil. "Developing Countries and Global Environmental Governance: From Contestation to Participation to Engagement." International Environmental Agreements: Politics, Law and Economics 5.3 (2005): 303-21. Print.

Najam, Adil, Saleemul Huq, and Youba Sokona. "Climate Negotiations Beyond Kyoto: Developing Countries Concerns and Interests." Climate Policy 3.3 (2003): 221-31. Print.

Ott, Hermann E., Wolfgang Sterk, and Rie Watanabe. "The Bali Roadmap: New Horizons for Global Climate Policy." Climate Policy 8.1 (2008): 91-95. Print. 
Pettit, Jethro. "Climate Justice: A New Social Movement for Atmospheric Rights." IDS Bulletin 35.3 (2004): 102-06. Print.

PWCCC, (People's World Conference on Climate Change). "People's Agreement." 2010. Web. November 12, 2011. <http://pwccc.wordpress.com/support/\%3E.

Roberts, J. Timmons, and Bradley C. Parks. A Climate of Injustice: Global Inequality, NorthSouth Politics, and Climate Policy. Cambridge, MA: The MIT Press, 2006. Print.

Sokona, Youba, and Fatma Denton. "Climate Chage Impacts: Can Africa Cope with the Challenges?" Climate Policy 1 (2001): 117-23. Print.

South-South Summit on Climate Justice and Finance. "Cancun Declaration." 2010. Web. March 5, 2011. <http://www.climate-justice-now.org/south-south-summit-on-climate-justiceand-finance $/ \% 3 \mathrm{E}$.

Tokar, Brian. Towards Climate Justice: Perspectives on the Climate Crisis and Social Change. Porsgrunn, Norway: Communalism Press, 2010. Print.

UNEP, (United Nation Environment Program). "Nairobi Declaration on the African Process for Combating Climate Change." 2009. Web. January 202010. $<$ http://www.unep.org/roa/Amcen/Amcen_Events/3rd_ss/Docs/nairobi-Decration2009.pdf\%3E.

UNFCCC. "Framework Convention on Climate Change." 1992. Web. March 30, 2009. $<$ http://unfccc.int/resource/docs/convkp/conveng.pdf\%3E.

Vihma, Antto. Elephant in the Room: The New G77 and China Dynamics in Climate Talks: The Finnish Institute of International Affairs, 2010. Print. 